\title{
ACRED WATER POOLS OF HINDU SACREDSCAPES IN NORTH INDIA
}

Rana P.B. Singh

Department of Geography, Institute of Science, Banaras Hindu University

Pravin S. Rana

Faculty of Arts, Banaras Hindu University

Sarvesh Kumar

Department of Geography, D.D.U. Gorakhpur University

\begin{abstract}
The basic metaphysical frame of life in ancient India, that of sacred water (pavitra jala) and the notion that "Water itself is life" (jala hi jivan hai), can be illustrated with case studies of two cities. Settled continuously since 1000 BCE, the cities of Varanasi and Ayodhya have been eulogized as the salvific holy-heritage cities in India known for their ritualscapes associated with sacred waters and pools. According to the ancient treatises and tales, there were fifty-four sacred tanks (kunds) and wells (küpas) in each of these cities, and they became important sites for purification rituals, pilgrimage, healing and festive celebration by devout Hindus. After providing descriptions of the sacred water pools, this essay in part explores traditions associated with a water-pool sacred to the Sun god in both the cities. More broadly, using ancient texts, present participatory surveys, and ethnological narration, the essay considers the long-lived sacrality of water pools in these holy cities and current development strategies involving them.
\end{abstract}

Keywords: Ayodhya, holy-heritage city, Lolark Kund, pilgrimage tourism, Suraj Kund, Varanasi

An ancient Hindu text, the Bhavishyottara Puranna (31.14) notes that "Water, thou art the source of all things and of all existence" (see Eliade 1958: 188). As elsewhere, waterfront or water-contact points were selected as sites of habitation in ancient India. Serving as memorials to ancestral settlement, these water sites were invested with sacrality and, over time, became places of rituals and festivities due in part to their healing qualities. As Ray has argued for Irish holy water sites, "competing, contested, contemporary and past tense, narratives reveal the multiple layers of meaning well sites have acquired through time" (Ray 2012: 154).

The basic metaphysical frame of life in ancient India has been that of sacred water (pavitra jala) and the notion "Water itself is life" (jala hij jivan hai). Humans everywhere settled along with perennial sources of water and most of the ancient holy-heritage cities in South Asia developed along rivers and springs (perceived as sacred) before further expanding around ponds and man-made wells and tanks. These acquired healing and supernatural qualities and remain associated with primordial symbols like Sürya (the Sun god, also known as Süraj) and the Nāga (a supernatural serpentine deity). 
This essay focuses on the holy-heritage cities of Varanasi and Ayodhya in the Ganga valley of north India (situated along the holy rivers of the Ganga and Sarayu, respectively). Continuously inhabited since $1000 \mathrm{BCE}$, these cities have been eulogized for their salvific ritualscapes associated with sacred waters. Both cities are known for the Shaivite and Vaishnavite traditions of religion, respectively. According to the ancient treatises and tales, there were sixty-four sacred tanks, known as kunds (or kundas), and holy wells (küpas) in each of these cities, around which sages established their resorts (äshramas) that became important sites for pilgrimage and healing. While some of these sacred water sites have been lost over time, most still exist and are the site where a variety of rituals have been continually performed. These sacred pools and tanks are used in purification rituals and festive celebrations by devout Hindus. In Varanasi, one of the most notable is Lolark Kund, while in Ayodhya one finds the huge pool of Sūrya (Süraj) Kund, which is attached to the famous ancient temple of Sūrya (the Sun god). The architectural superstructures and natural settings of both sites are now being conserved and developed by the state government for spiritual and pilgrimage tourism. Using descriptions in the ancient texts, participatory surveys, and ethnological narration, this essay considers the long-lived sacrality of sacred pools in these holy cities and the current development strategies involving them. The authors offer anthropological and Indological perspectives on sacred water pools, while further mapping selected sites and considering their status in developing pilgrimage tourism.

\section{Sacred water-pools: the context of ancient tales}

The cult of living water is described in Vedic literature (ca. 2500-500 BCE) and elaborated more vividly in Puranic literature (ca. 500 BCE-CE 700). An important physical and conceptual resource, water has cosmological connotations in various mythologies (Singh 2013: 160). Water and religion are bound to each other. Often central to religious cosmogony, water can be understood as a manifestation of the divine or is held to be governed by a divine being or beings. Water may be associated with sexuality, or otherwise perceived to be involved with the generation of life, or with healing, purification, or sacralization. Water, perhaps more than any other natural resource, is employed as a profound spiritual symbol and an object of worship. In one of the earliest Hindu hymns, the healing quality of water is praised (Rig Veda, 10.9.8-9, see Pannikar 1985: 108, and Baartmans 2000: 207):

Whatever sin is found in me, whatever wrong I may have done, if I have lied or falsely sworn, Waters, remove it far from me. .... 10.9.8.

Now I have come to seek the Waters.

Now we merge, mingling with the sap.

Come to me, Agni (fire), rich in milk!

Come and endow me with your splendor! ... 10.9.9 


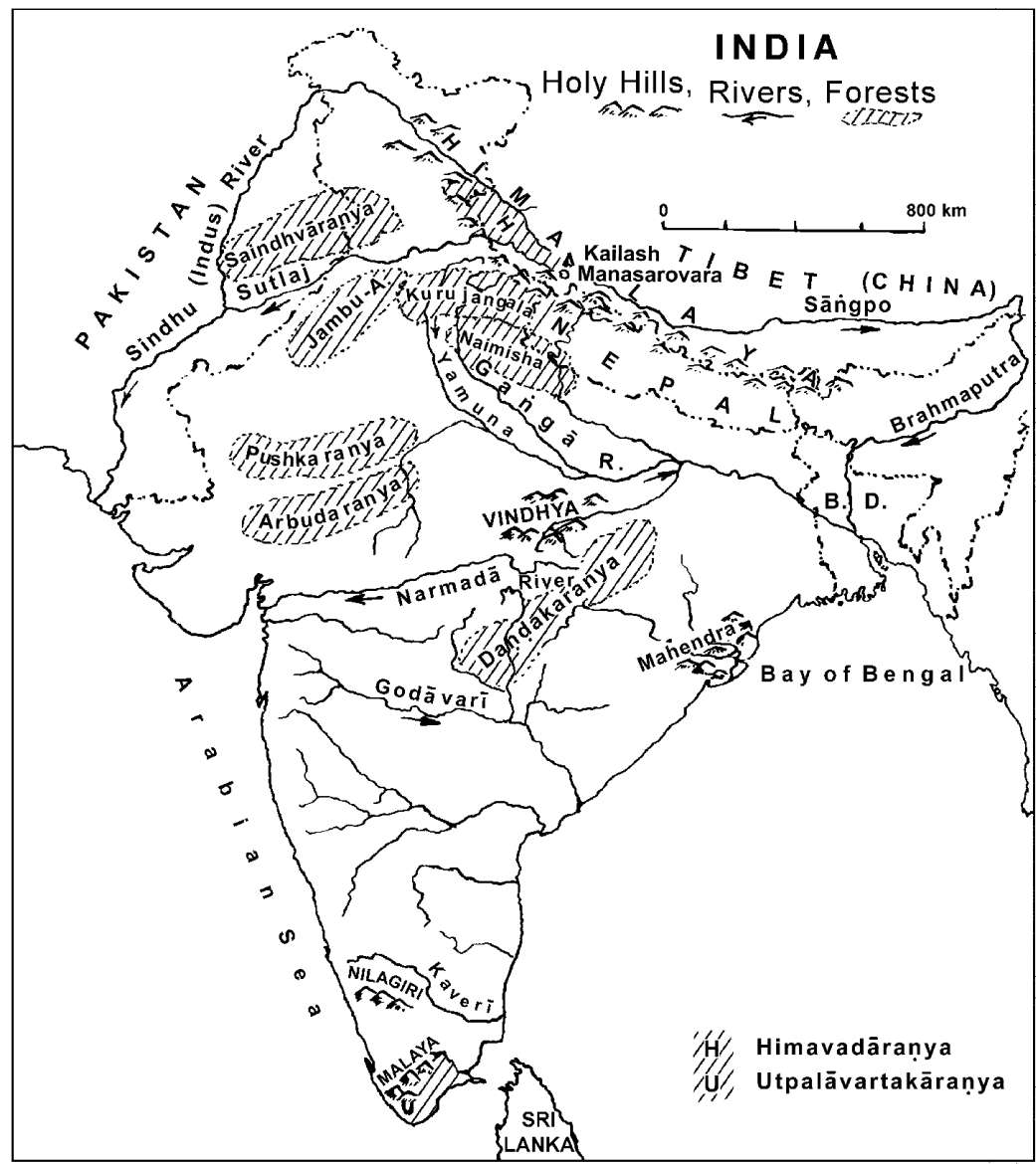

Figure I. Sacred India: The Holy Hills, Sacred Rivers, Forests and Sarovars. (Source: Singh and Rana 2016: 78, reprinted with permission).

The veneration of water has significantly shaped Hindu religious and pilgrimage traditions (Alter 2001). The oldest text of Hinduism, the Rig Veda (RgV) (ca. 2500 BCE) describes water as the "greatest gross-element of life which pervades all, holding the embryo, and producing agnih [heat]" (RgV 10.121.7, cf. Singh, Rana and Olsen 2022: 138-139), and characterizes water as having a life-infusing power and motherly qualities ( $\mathrm{RgV} 1.23 .20,6.50 .7)$. Along with mountains, water is one of the most sacred symbols in Hinduism. Rivers, tirthas (sacred places along rivers), and confluences of rivers are considered sacred, and bathing in these water bodies allows a person to experience cosmic energy and be purified of sins (Agoramoorthy 2015; Singh 2020). Of all the rivers in India, the seven most holy are the Ganga, Yamuna, Godavari, Sarasvati, Narmada, Sindhu (Indus), and Kaveri (cf. Fig. 1), making the whole of India intensely sacralized. This has powerfully promoted the development of a huge mass of sacred places along these rivers, in addition to replicating other such sacred places from various parts of India in the frame of spatial transposition. Small ponds (kunds) 
and lakes (sarovars) are also considered sacred, and the majority of them are linked to natural springs and/or sacred perennial rivers (cf. Singh, Rana and Olsen 2022). Holy wells may be defined, similarly to those elsewhere in the world, as "any natural source of freshwater that is a focus for ritual practice and engagement with the supernatural, which may possess a cure for particular ailments and receive votive offerings. ... The 'well' of 'holy well' is not a human-excavated hole or shaft for water collection; holy 'wells' are natural features and are most commonly springs, but can also be ponds, lakes, and even ponds fed by seepage" (Ray 2019: 265).

The Bhàgavata Purāna (6.5.3), dated to the sixth century CE, eulogized five holy lakes (sarovars), which are linked to sources of natural springs and are associated with the creation myth at different levels symbolizing primordial water. They are therefore eulogized as sacred and propitiated by the great sages of the ancient past and thus constitute an important part of sacred bathing during pilgrimages. Their glory and importance in religious activities and cleaning rituals are narrated in ancient epics like the Rāmāyaña and the Mahābhärata (see Kane 1975, vol. III: 1400-1471). The main characteristics of the five sarovars (holy lakes) are presented in Table 1.

Table I. Pancha Sarovars (holy lakes) and their characteristics.

\begin{tabular}{|l|l|l|l|l|}
\hline Se & $\begin{array}{l}\text { Sarovar, holy lake, } \\
\text { and (location) }\end{array}$ & $\begin{array}{l}\text { Deity/ saint } \\
\text { affiliation }\end{array}$ & $\begin{array}{l}\text { Links to the ancient } \\
\text { tale }\end{array}$ & Religious merit \\
\hline 1 & $\begin{array}{l}\text { Manasarovar } \\
\text { (Tibet, China) }\end{array}$ & $\begin{array}{l}\text { "Heart of the divine } \\
\text { world": Buddhism, } \\
\text { Hinduism, Jainism, } \\
\text { and Tibetan Bon }\end{array}$ & $\begin{array}{l}\text { a Shakti Pitha, where } \\
\text { the right palm of Devi } \\
\text { fell; site of the Fish- } \\
\text { incarnation of Vishnu }\end{array}$ & $\begin{array}{l}\text { Liberation from } \\
\text { transmigration } \\
\text { (mukti) }\end{array}$ \\
\hline 2 & $\begin{array}{l}\text { Bindu Sarovar } \\
\text { (Siddhpur, Gujarat) }\end{array}$ & $\begin{array}{l}\text { sage Kardama and his } \\
\text { son Kapila }\end{array}$ & $\begin{array}{l}\text { Shiva filled this } \\
\text { lake with holy } \\
\text { water; known as the } \\
\text { Kapalamochan tirtha. }\end{array}$ & $\begin{array}{l}\text { Blessings of } \\
\text { the (feminine) } \\
\text { manes; and } \\
\text { cleansing of sins }\end{array}$ \\
\hline 3 & $\begin{array}{l}\text { Narayana Sarovar } \\
\text { (Koteshvar temple, } \\
\text { Kutchh, Gujarat) }\end{array}$ & $\begin{array}{l}\text { Vishnu and Rama, } \\
\text { saint Vallabhacharya }\end{array}$ & $\begin{array}{l}\text { Vishnu's resting } \\
\text { place; symbolizes } \\
\text { Chhirasagar }\end{array}$ & $\begin{array}{l}\text { Blessings of } \\
\text { Vishnu; cleansing } \\
\text { of sins }\end{array}$ \\
\hline 4 & $\begin{array}{l}\text { Pampa Sarovar } \\
\text { (Koppal, } \\
\text { Karnataka) }\end{array}$ & $\begin{array}{l}\text { Rama, and devotee } \\
\text { Shabari (a female } \\
\text { ascetic described in } \\
\text { the Rāmāyana) }\end{array}$ & $\begin{array}{l}\text { Vishnu and seven } \\
\text { ancient sages; } \\
\text { nearby Anjani hill } \\
\text { (Hanuman's mother's } \\
\text { temple) }\end{array}$ & $\begin{array}{l}\text { Blessing of } \\
\text { Savitri; cleansing } \\
\text { of sins }\end{array}$ \\
\hline 5 & $\begin{array}{l}\text { Pushkar Sarovar } \\
\text { (Ajmer, Rajasthan) }\end{array}$ & $\begin{array}{l}\text { Brahma, the progeny } \\
\text { in the Trinity; three } \\
\text { sarovars linked } \\
\text { together. }\end{array}$ & $\begin{array}{l}\text { Savitri (Sarasvati), } \\
\text { goddess of knowledge }\end{array}$ & $\begin{array}{l}\text { The first water } \\
\text { progeny; } \\
\text { cleansing of sins; } \\
\text { place of ancestral } \\
\text { rituals }\end{array}$ \\
\hline
\end{tabular}

(Source: based on Gita Press 1957: 68, 533, 55I, 410 and 385, see Figure I; see, Singh, Rana and Olsen 2022: I40) 


\section{Varanasi (Banaras): kunds/ sacred ponds}

The sacred territory of Varanasi (also known as Banāras) has long been a beautiful waterscape, with its borders demarcated on the east by the Ganga River, the north by the Varana River, and the south by the Asi River. Historically, the city recorded 108 water ponds (Hindi: tâlāb, Sanskrit: kunda), sixty-four of which existed as late as the mid-nineteenth century, which were linked to a series of streams dividing the city into five forest tracts (vana) - from north to south these were the Mahā Vana, Dāru Vana, Ānanda Vana, Harikesha Vana, and Bhādra Vana. An 1822 map of Varanasi made by British scholar James Prinsep clearly shows how numerous these pools and holy ponds were (Fig. 2). His drawing shows how, in the north, the forest tracts of Mahā Vana and Dāru Vana were divided by a stream linking Mandakini and Matsyodari, which further met the sacred site of Rinamochana before ultimately flowing into the Varana River. One part of this stream, during heavy rains, once met the Ganga River near Manikarnika Ghat (a ghat is a set of steps leading to the water that often serves as the site of water-related rituals). The overflow of this water connected the water pools of Bhulotana Garha, Benia Talab, Suraj Kund, and MisirPokhara before it finally met the Ganga River at Dashashvamedha Ghat. Though most of these water bodies no longer remain, during heavy rains or floods (as occurred in the years 1948, 1978, 1992, 2013, and 2017), the channels make themselves and their former routes known again.

In contemporary urban Varanasi, most water sites (wells and ponds) lie in a state of disrepair, except for five which have undergone sporadic "beautification" by governments or local associations. However, wells and their significance are known to elder inhabitants of the city who still recall the diverse healing qualities and ritual importance of their waters (Lazzaretti 2020: 161). The city's entire waterscape has been seen as a framework through which inhabitants construct their own categories and understandings of time and space (see Derné 1998). Despite such changes to the landscape, the importance of sacred ponds is not lost; in fact, inclusive heritage development planning recognizes their significance for the conservation and promotion of intangible heritage.

On the banks of these sacred ponds, religious activities, fairs (melās), and bathing rituals occur on dates considered to be auspicious. These sites and their associated practices are eulogized in mythological literature and continue to be maintained by Hindu traditions. "Glorifications," (descriptions of pilgrimage sites and cities) often describe sacred water sites. Some water sites are notable for specific activities; three of them (namely Pishachmochana, Kapiladhara and Chakrapushkarini Kunds) specialize in pacifying particular types of deceased persons with offerings (Singh 1994: 223). Pishachmochana, for instance, is considered the proper place to perform offerings for those who have turned into erratic goblins and haunting spirits (bhüta, preta, pishächa) as a result of death due to illness or violent accidents.

The mythological literature, such as the thirteenth-century Käshì Khanda (hereinafter $K K h$ ) mentions not only sixty-four sacred ponds, but also six larger wells ( $v \bar{a} \bar{p} \bar{s}$ ) and thirty-one sacred wells (kūpas) in Varanasi. With population growth, the 
expansion of settlements, and changing life philosophies, many water sites have been lost or encroached upon by residential quarters. The notable ones are still active and part of the current programs of sustainable development and appraisal of cultural and religious sites under the national mission of PRASAD (Pilgrimage Rejuvenation and Spiritual Augmentation Drive), initiated by the Government of India in 2014-15. One aim of PRASAD is promoting integrated and sustainable development of heritage sites associated with sacred water. In the city of Varanasi, the five sacred water pools have been selected in this mission and are described below.

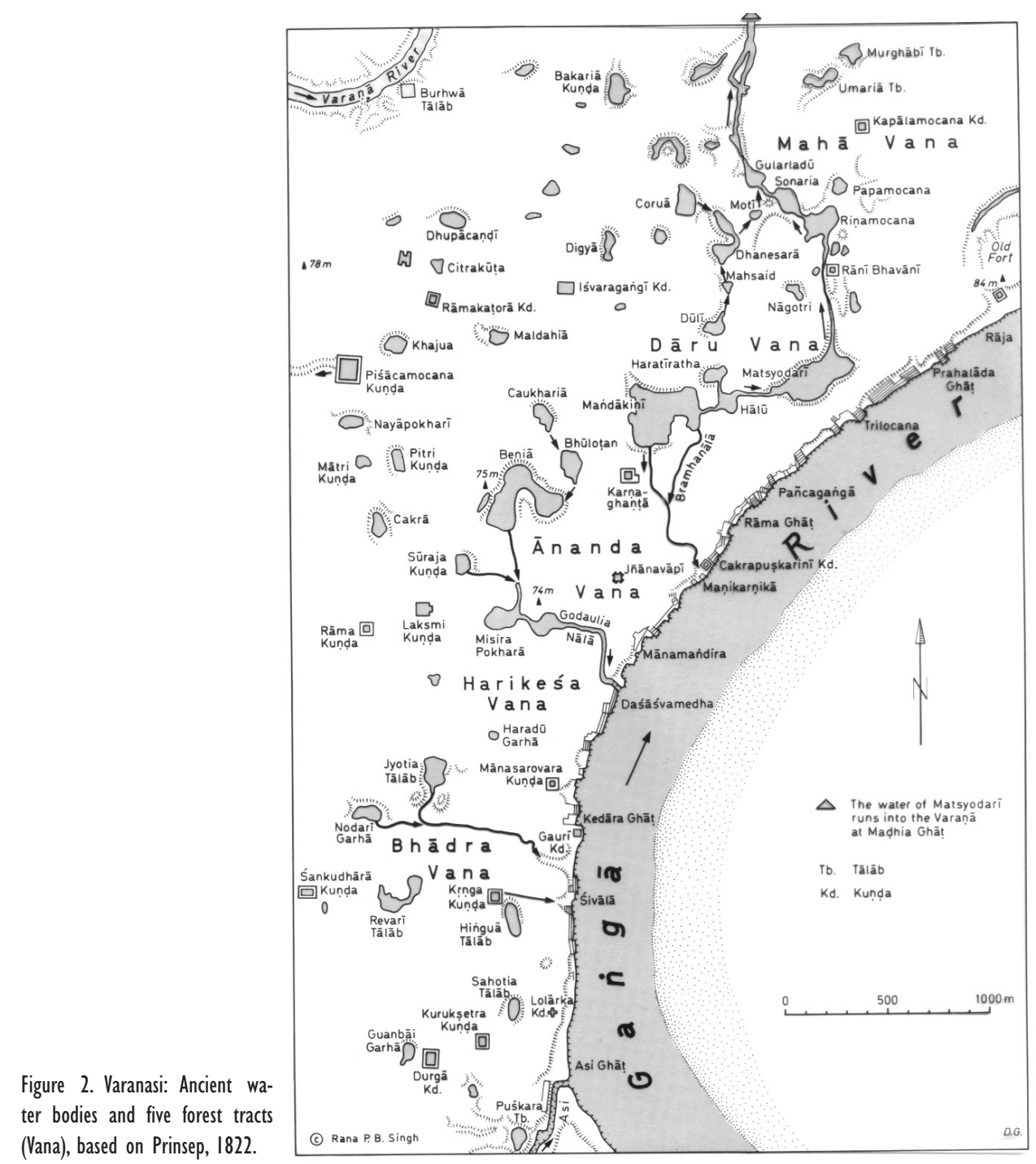




\section{( I) Jnanavapi ("Well of Wisdom")}

According to the $K K h$, the Jnanavapi (or "Well of Wisdom") symbolizes the primordial water associated with the story of Ishana (Shiva's form controlling the northeast realm of the universe), who dug the earth at this site with his trident and offered the water to Avimukteshvara, the most ancient form of Shiva in Varanasi (KKh 33.17, 18). The KKh (33.50) further notes that Shiva promised to take up his abode in the well in liquid form and reside there to destroy ignorance and provide wisdom (jūana). He later occupied the temple built alongside the well, but when that temple was demolished in 1669 by the order of Mughal king Aurangzeb, Shiva took refuge in the well and has resided there ever since. Jnanavapi is the highest among all the pilgrimage centers, as a direct manifestation of wisdom, giver of all sorts of knowledge, preserver of merits of all the lingas, and the most auspicious and direct manifestation of Shiva, and is held to have been in Varanasi long before the Ganga came to earth (KKh 34.123; see Lazzaretti 2020: 164-165).

During most sacred journeys and rituals, pilgrims first go there to sip the water when taking the vow to initiate their pilgrimage (saikalpa lenā) and another upon its completion (saikkalpa chodānā). Surrounded by a low-roofed colonnade comprising stone pillars arranged in four rows, the well is presently protected with iron bars and a cloth across the top to prevent coins, flowers, and ritual items of pilgrims from falling or being thrown into it.

The development of the Kashi Vishvanatha Tirtha corridor is a part of a megaproject initiated in 2019 for the revival of the ancient glory of the city. The corridor is the sacred heritage area around the patron deity temple of Vishvanatha. Vitally, Jnanavapi will serve as the main site for purification rituals. Around this well will be planted sacred healing herbs and trees that can supplement nature-based medical practices and serve in ritual use. These include tulasi/holy basil (Ocimum sanctum basilica), shami (Acacia suma), nima (Azadirachta indica), pipal (Ficus religiosa), vat/banyan/ Indian fig (Ficus bengalensis), and flowering plants like harsingar (Nyctanthes arbortristis), chameli (Jasminum pubsecene), and kanair (Nerium odorum). This project is expected to reach completion by the end of 2022.

\section{(2) Manikarnika or Chakrapushkarini Kund}

The mythology given in the KKh $(60.137-138 ; 61.83-85)$ tells us that, for the benefit of the three worlds, the mythic king Bhagiratha brought the Ganga River to Shiva's Forest of Bliss (änandavana) and Vishnu's Lotus Pool, where the pool known as Manikarnika Kund is located. This is eulogized as the "Door of Heaven," located close to the ghat (a stairway to the water bank), around which the cremation ground is situated. This is the place where post-cremation bathing is performed, and throughout the year pilgrims make oblations there. The kund, surrounded today by a cast-iron railing, is some sixty square feet at the top and narrows to about twenty square feet at the water's edge. This kund is believed to be the world's first pool and is held to be the first holy spot dug-out at the dawn of time and filled with the sa- 
cred water of Lord Vishnu's perspiration. Vishnu's footprints are visible there as a testimony to that story. Before purifying themselves in the sacred water, Hindu pilgrims first pray at the marble slab that bears Vishnu's footprints. Millions of Hindus have sprinkled it with holy water and adorned it with flowers. Whenever a Maharaja (king) of Banaras died, it is alongside these footprints that he was cremated.

Each year when the Ganga recedes, the water leaves behind a huge mass of alluvial silt in the tank. During the peak floods the kund is completely inundated and often disappears from view, as in August 1993, July 2013, and August 2017. When floods and waters recede, gradually the excavation and reclamation of the silt begins, to be completed by Shivaratri (the new-moon day of February-March, i.e., the wedding day of Shiva). On this occasion, a grand celebration takes place, attended by over five thousand people. The pilgrims passing along this route perform special rituals in honor of their ancestors and the celebration concludes with rituals of thanksgiving. The state government now includes Shivaratri on its list of intangible cultural heritage. This designation encourages on-site participation in a full-day festival when large numbers of pilgrims from South India participate.

\section{(3) Durga Kund}

The temple of the goddess Durga is in the southern extremity of Varanasi and is associated with a sacred pond, named after her (Fig. 3). According to mythology, Durga protects the city from the south and is said to have rested at Durga Kund after slaying a mythic demon. Durga is also known here as Kushmāṇdā ('Pumpkin Gourd'), one of her nine manifestations. On every Tuesday, and even more frequently in the month of Shravana (July-August), worshippers perform rituals at this site. Presently the water of the pond is so polluted that only a few pilgrims dare to bathe; in fact, most of them put only a few drops of this water upon their head as a mark of the purificatory rite. Pilgrims performing sacred journeys like the Nagara Pradakshina ("pilgrimage around the city"), Kedara Khanda (the sacred segment of Kedara) and Panchakroshi (the outer sacred circuit) pass-through this site and perform rituals. During the month of Shravana (July-August), a religious fair is held and attended by an enormous multitude of people. Both sides of the road are decorated with festooned vendor stalls selling sweets and ritual items. The other two periods of mass visitation are the first through the ninth day of the dark-fortnight (waning moon) of Chaitra (March-April) and again in Ashvina (September-October). Every year, before the start of the festive month of Shravana (July-August), the municipality of Varanasi, assisted by local religious groups and community organizations, renovates and cleans the water pool and its environs to support and enhance the celebrations.

Close to this sacred pond lies Kurukshetra Kund, which is famous for the bath taken there on the occasion of a solar eclipse. This tank was constructed by Queen Rani Bhavani of Bengal in about 1775 (in commemoration of an epic battle fought at Kurukshetra and described in the Mahäbhärata, estimated to have been written in the twelfth-century BCE). This tank is square and built with stone stairs that lead down to the water. During the Hindu month of Shravana (July-August), and on the occa- 
sion of the solar eclipse, this water pool is cleaned, and related structures are repaired to better serve the devout local Hindus and pilgrims from the neighboring districts.

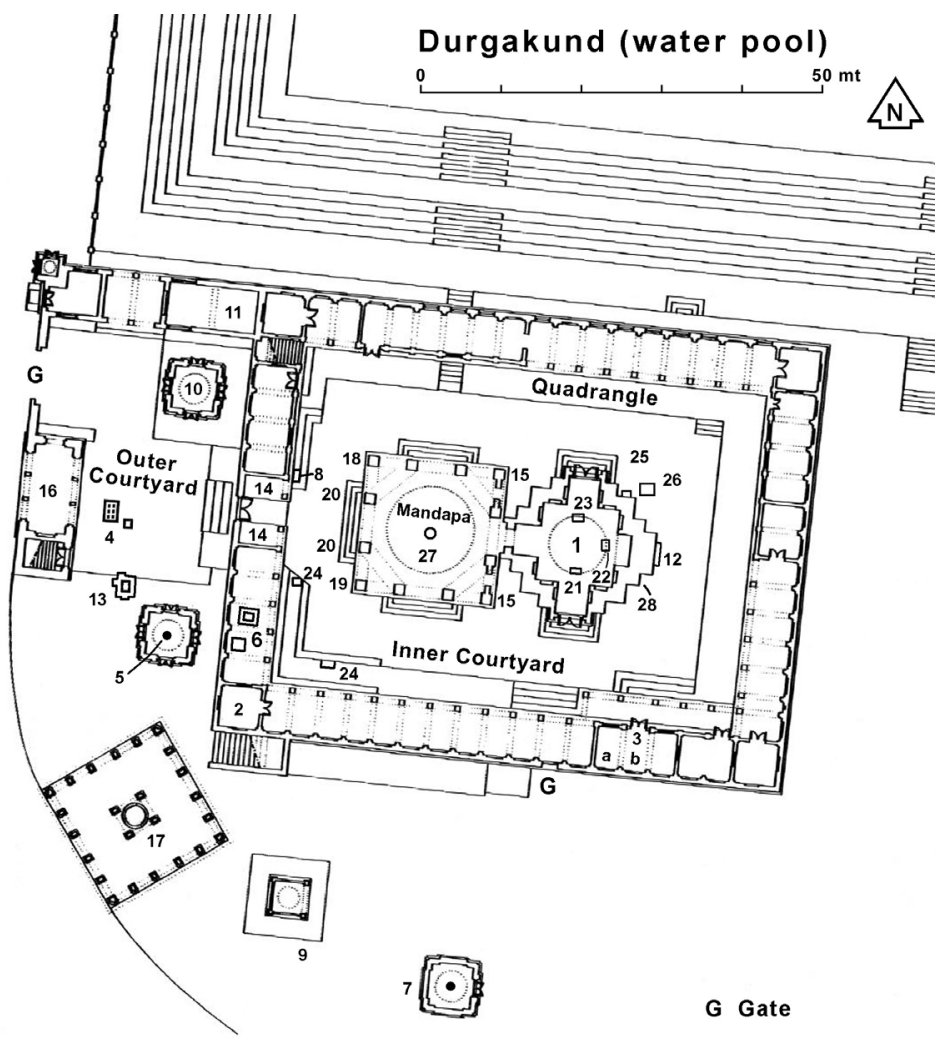

1 Durga; 2 Bhadrakali, Chanda Bhairava, Tantric Kali; 3 a Sarasvati \& b Lakshmi; 4 Sacrificial plot and pillar; 5 Tilaparneshvara or Jaleshvara; 6 Fire pit (Havan Kunda); 7 Kukkuteshvara Mahadeva; 8 Ganesha \& Sheshanaga; 9 Jvalahareshvara/ri; 10 Surya (Sun-god); 11 Krishna-Radha; 12 Eight-petalled lotus; 13 Lion Pillar; 14 Stone Pillar; 15. Brass Lions; 16 Naubhat Khana (drum room); 17 Dharmashala (pilgrims' shelter); 18 Hanuman; 19 Bhairava; 20 Dvarapala (guards);

21 Mahishasuramardini; 22 Krishna Gopala; 23 Lakshmiu Narayana; 24 Brass bells; 25 Sanctified water (Charnamrita); 26 Rudra Bhairava; 27 Mandapa (pavilion); 28 Shikhara \& Sanctum.

Figure 3. Varanasi: Durga Kund and Durga temple. The water pool serves as a centripetal force around which the whole temple complex and sacred sites developed.

\section{(4) Naga Kupa (Serpent Well)}

This step-well is believed to be associated with ancient sages, Patanjali and Panini, the great grammarians, who lived over two thousand years ago. This is the water site where Nāgās (supernatural snakes) are honored to this day, especially on the festive day of Naga Panchami during the rainy season in the month of Shravana (July-August) (Eck 1982: 226, also Sherring 1868: 220). In ancient literature, this is referred to as Karkotaka Vapi and was glorified for its healing qualities, notably for providing 
relief from snake poison (KKh, 66.9-12 and 23-6). As Ray notes, in most ancient cultures, snakes are "ubiquitous supernatural protectors and residents of sacred waters. Except in a few cases of obvious diffusion, water-dwelling serpentine beasts appear so regularly in tales around the world because of the centrality of water in mythic cosmologies and an almost panhuman fascination with the silently undulating and sidewinding snake" (Ray 2020: 13). On the festive day of Naga Panchami, a great religious fair (mela) takes place and thousands of devout Hindus bathe in the deep well (Fig. 4) and honor its serpent deities, including Shiva as lord of snakes (Nageshvara). People believe that the water in this deep well emerges from the netherworlds (pätāla) ruled by the serpent king Vasuki (see Eck 1982: 264).

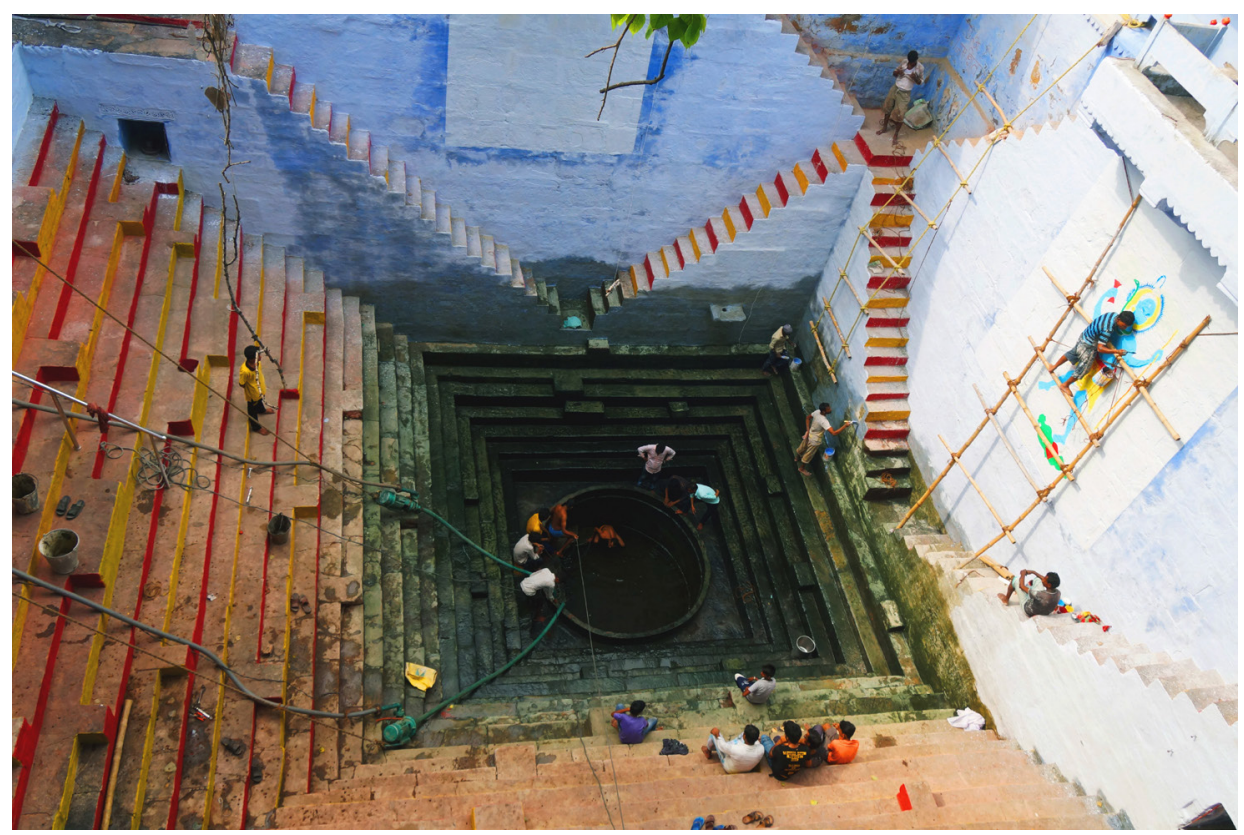

Figure 4. Naga Kupa, the step-well related to serpent worship (with courtesy from Rakesh Prajapati).

\section{(5) Lolark Kund ("Well of the Trembling Sun"): a case study}

Of the twelve sun shrines of the city, Lolark is the most famous and marks the southern edge of the city. Lolark is attached to a steep well, which is accessible from three sides with flights of steps leading down sixteen meters to the very bottom (Gutschow 2006: 240, see Figs. 5a and 5b). Its first reference appears in an eighth-century BCE text, the Shatapatha Brähmana (VI. 1.28), which describes twelve suns associated with twelve solar months. Long before the formation of Hinduism, Lolark was connected to sun and snake worship and remained so even during Buddha's time. The eleventh-century Gahadavala kings were famously devoted to the site. Presently, Lolark Kund is a sun and Shaivite site of worship that reflects a complex history of gradual mythological fusion, and it remains a powerful place that annually draws 
tens of thousands of Hindus. Eulogizing this kund, the Käshī Khanda (46.67) states that the water of Asi River and the rays of the sun god Lolark work together to erase the sins of those who come to Varanasi. Bathing in this kund provides the merit of purification from sin and disease and a blessing for life and fertility. This place is the southern boundary of a spatial arrangement of 14 solar shrines in the city (two of which have been replaced over time).
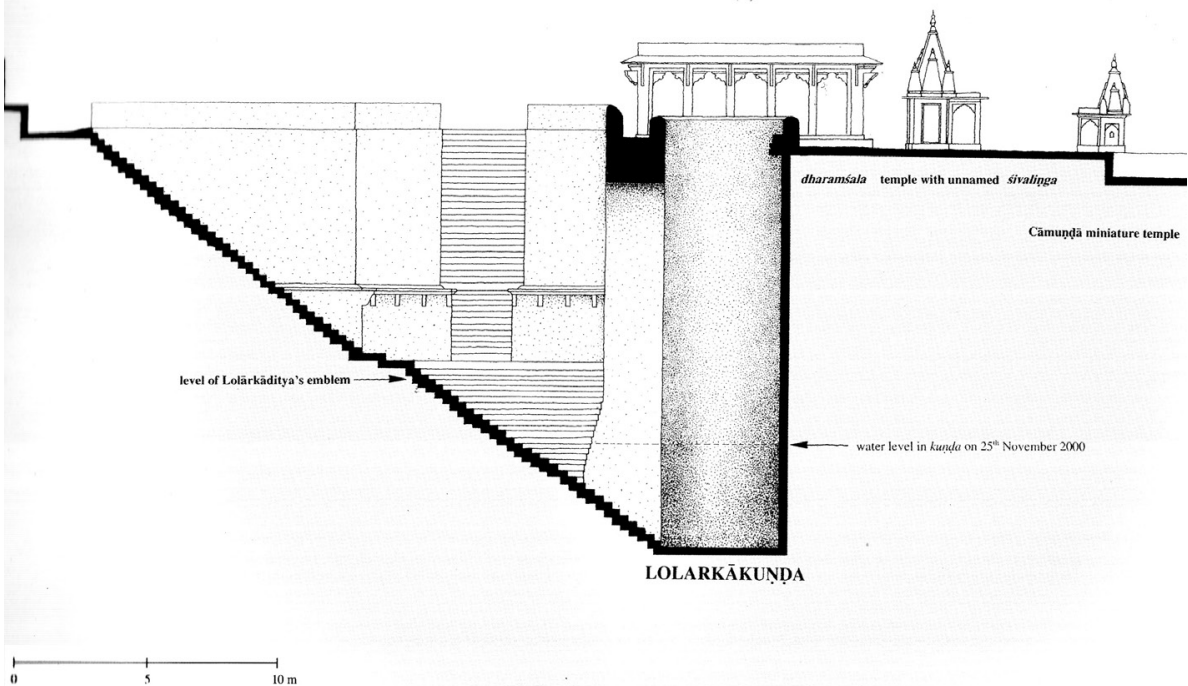

Figure 5a. Lolark Kund: a cross-sectional view (after Gutschow 2006: 240, reprinted with permission).

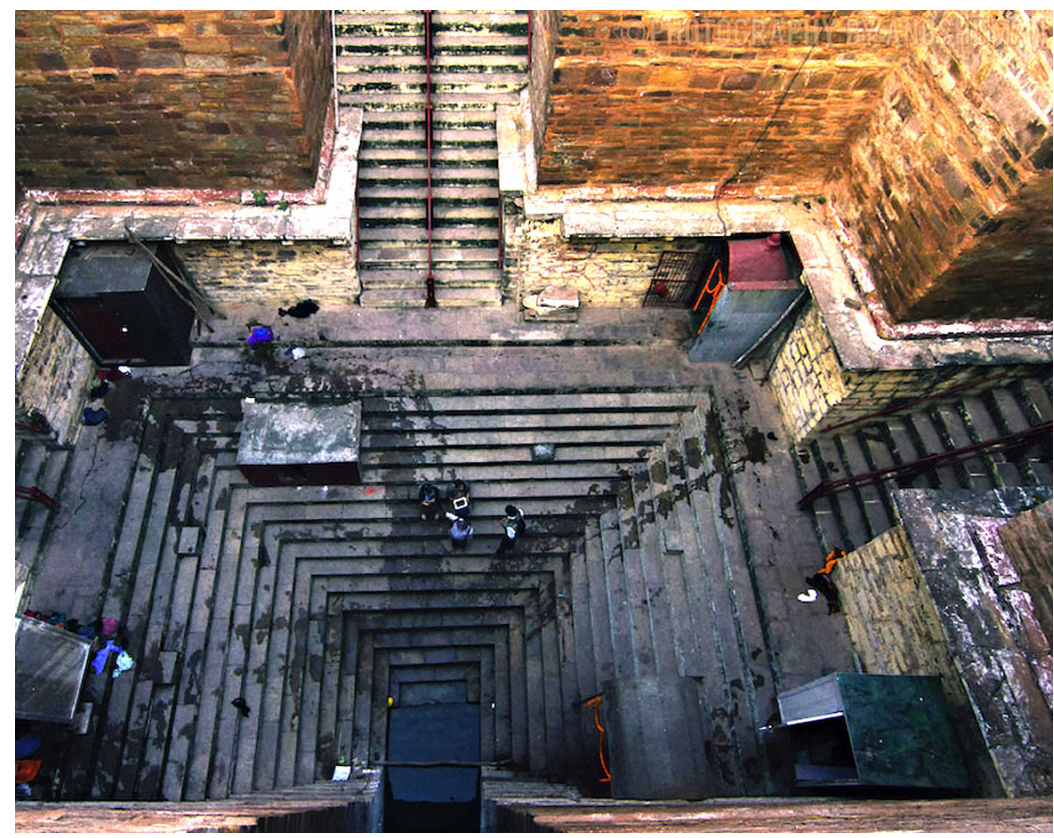

Figure 5b. Lolark Kund: an overview from the east (lower side) to west (upper side). 
This holy well reflects upon an ancient myth of fertility associated with the sun god as a supreme and primordial deity. Oral history relates that the sun god became Lol (excited) upon seeing the nude beauty of Ghritachi (a celestial dancer in the court of Indra) and that his spilled semen is preserved in the spot. This myth encouraged young women to come here and have a ritual dip to guarantee conception. Such a visit was followed by another, this one celebrating conception, and another celebrating the birth of a child. On every Sunday many people still take baths and worship the trembling sun god Lolarka and a nearby linga of Lolarka-Shiva (Lolarkeshvara). The sixth day of the waxing fortnight of Bhadrapada (August-September) is the most auspicious day, Lolarka Shasthi/Chhatha (Lalahì Chhatha), when tens of thousands of worshippers, mostly women, bathe in the step-well to receive bliss for their sons and their wellbeing. This festival is performed almost exclusively by married Hindu women from the Bhojpur region of Bihar and Uttar Pradesh. The women's main object of worship is the sun goddess, revered as Chhathī Māi, who is seen as the female energy that bestows fertility and cares for children (Singh 2010: 78). This festival is also recognized as an example of intangible cultural heritage (ICH), and as such is integrated within new inclusive heritage development promoting pilgrimage tourism.

An eleventh-century image of the goddess Chakreshvari, consort of BhairavaShiva, was found here, and thus it has been interpreted that this site was once associated with goddess worship and that, over time, it became unified with the deity's husband and accepted as the site of a fertility cult (see Pathak and Humes 1993: 238). This kund maintains its popularity as a site of a non-Brahmanical fertility ritual. Both vow-taking and thanksgiving rites are performed on this occasion. Most pilgrims who come here to perform thanksgiving have earlier received offspring and perform the tonsure of small children (mundana) as a rite of passage at the same spot. As is customary since the early nineteenth century, after bathing and performing rituals at this site, pilgrims proceed about half a kilometer northwest to Kringa Kund, associated with the Tantric sage Kina Rama, where they again bathe and sing religious songs (see Singh 2010: 68-69).

We have made a longitudinal study of the frequency of devout Hindus visiting and performing rituals at Lolark Kund on the festive day of Bhadrapada Shukla $6^{\text {th }}$ (the sixth day of the waxing fortnight in August-September), which fell between August $12^{\text {th }}, 2009$ and September $4^{\text {th }}, 2019$ (see Tables 2 and 3). Visitation took place in two main periods (in the early morning and in the late morning until noon). Over $80 \%$ of the attendees were females, both young and old (cf. Tables 2 and 3 ). As noted, around $75 \%$ of the visitors recorded their presence by noon. The same tendency was noted in an earlier study (see Singh 2010). 
Table 2. Lolark Kund, Varanasi: the festival of Lolarka Chhatha (Bhadrapada Shukla $6^{\text {th }}$, Samvata 2076); 04 September 2019, Wednesday: Frequency of devout Hindu visits.

\begin{tabular}{|l|r|r|r|r|r|r|r|r|r|r|}
\hline \multirow{2}{*}{ Age, yr } & \multicolumn{3}{|c|}{$05.00-08.00$ AM } & \multicolumn{2}{|c|}{$08.00-13.00$ NOON } & \multicolumn{5}{|c|}{ TOTAL } \\
\cline { 2 - 12 } & Male & Female & Total & Male & Female & Total & Male & Female & Total & \multicolumn{1}{l|}{} \\
\hline$<15$ & 135 & 192 & 327 & 301 & 328 & 629 & 436 & 520 & 956 & 8.7 \\
\hline+15 & 179 & 873 & 1052 & 431 & 2,069 & 2,500 & 610 & 2942 & 3,552 & 32.3 \\
\hline+40 & 224 & 1,235 & 1459 & 369 & 2,452 & 2,821 & 593 & 3,687 & 4,280 & 39.0 \\
\hline+60 & 113 & 795 & 908 & 168 & 1,123 & 1,291 & 281 & 1,918 & 2,199 & 20.0 \\
\hline Total & 651 & 3,095 & 3,746 & 1,269 & 5,972 & 7,214 & 1,920 & 9,067 & 10,987 & 100.0 \\
\hline
\end{tabular}

(Source: personal and group survey by authors).

Table 3. Lolark Kund, Varanasi: the festival of Lolarka Chhatha (Bhadrapada Shukla $6^{\text {th }}$ ): Frequency of devout Hindu visits, 2009 and 2019.

\begin{tabular}{|l|c|c|c|c|c|}
\hline \multirow{2}{*}{ Age, yr } & \multicolumn{2}{|l|}{ (a) 12 August 2009 } & \multicolumn{2}{l|}{ (b) 04 September 2019 } & (c) \%age Variation: \\
\cline { 2 - 6 } & Total & $\%$ & Total & $\%$ & -17.58 \\
\hline$<15$ & 1,160 & 10.7 & 956 & 8.7 & 2.21 \\
\hline+15 & 3,475 & 32.1 & 3,552 & 32.3 & 4.36 \\
\hline+40 & 4,101 & 37.8 & 4,280 & 39.0 & 4.66 \\
\hline+60 & 2,101 & 19.4 & 2,199 & 20.0 & 1.38 \\
\hline Total & 10,837 & 100.0 & 10,987 & 100.0 & \multicolumn{2}{c}{} \\
\hline
\end{tabular}

(Source: personal and group survey by authors; for 2009, Singh 2010: 72).

It is noted that no noticeable change has been recorded during 2009-2019, mainly due to consistency in Hindu traditions and practices, although the tune of celebrations changed according to travel type and the technology of the time. More decorations focused on Hindu identity and musical performances were part of the celebrations. After the Covid-19 lockdown of March 2020, the festival was abbreviated, though it was maintained by around forty selected local priests and functionaries to continue the tradition on 24 August 2020 and on 12 September 2021.

\section{Ayodhya: water pools}

As at all the holy-heritage cities, from the ancient-period kunds and sars (small natural ponds) have played an important role in Hindu purificatory rituals in addition to being an essential source of water for the city of Ayodhya (see Kumar and Singh 2013: 11). Here some kunds are in natural forms without any human construction, while others have steps constructed on all sides. Many of these kunds are attached to the pilgrimage routes of the Chaudahkroshi pilgrimage path and the Panchakroshi circumambulation path, but some are scattered along the inner pilgrimage path (antargriha) 
of the city (Fig. 6). The inner-most circuit runs around the patron temple of Ramajanmabhumi. These three pilgrimage routes are archetypally described as macro-, meso- and micro-cosmic circuits, respectively. In ancient texts, thirty-six waterfront sacred places are mentioned, including thirty-three kunds; however, at present, only nineteen are surviving, out of which two are now deserted and four are not in regular use (see Bhagiratharam 2013: 49-101). These kunds and the associated pilgrimage routes are now part of the inclusive heritage development plan for Ayodhya (20212041). The religious importance and associated activities at these twelve kunds are described below and the most prominent one, Surya Kund, is taken as a case study.

Figure 6. Ayodhya: the holy tanks (kunds: A- Active, R- Ruined, and L- Lost).

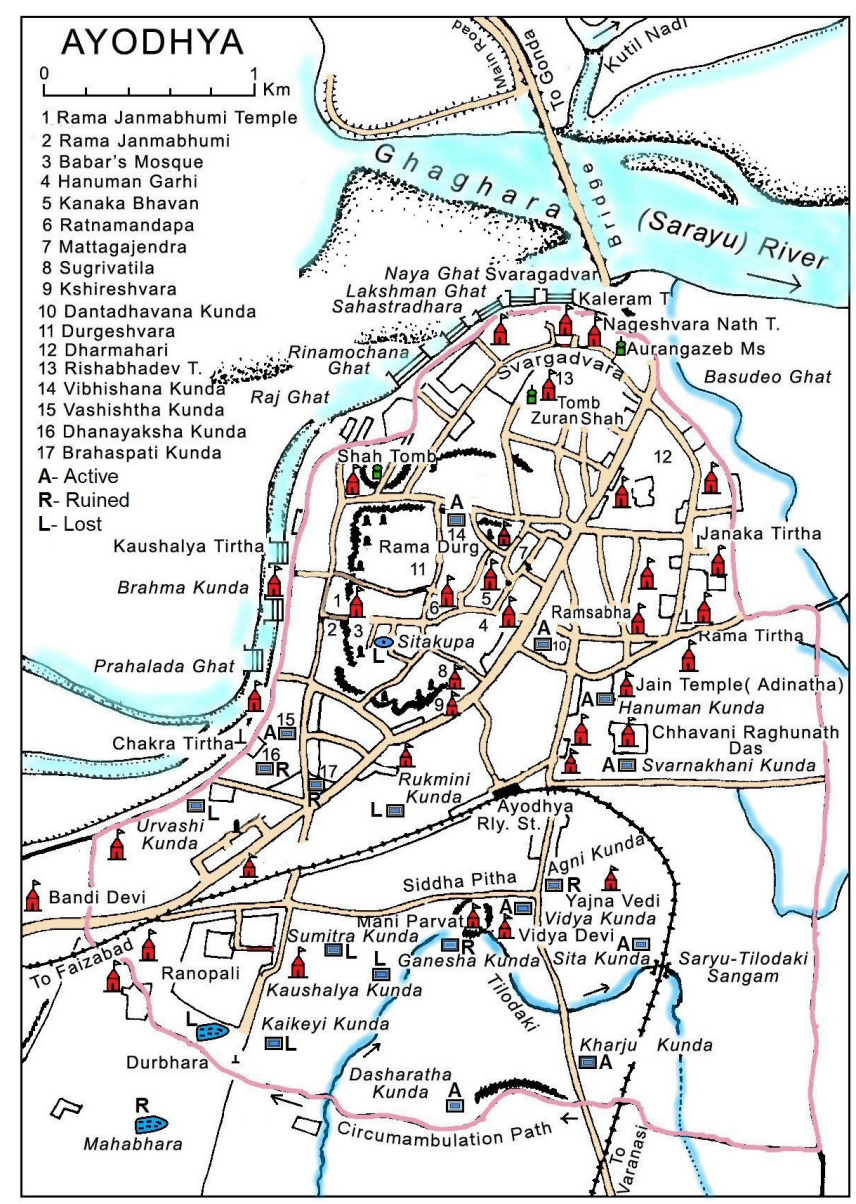

\section{( I) Dantadhavan Kund}

Dantadhavan Kund has long been used for ritual brushing of the teeth and washing the face in the morning time. According to the Chinese pilgrim Fa-hsien (Faxian), ca. CE 5th century, a tree was found just south of the city that had grown out of 
willow sticks used by the Buddha to clean his teeth, but some jealous Brahmins cut down the tree. During the sixteenth and seventeenth centuries, when ancient Ramaite sites were being recovered all over the place, such a local legend might have prompted the rediscovery of the spot where Rama was believed to have brushed his teeth. Thus, Dantadhavan Kund sprang into existence (Bakker 1986: 111). This kund is well-maintained, with steps on all the sides, and affords a beautiful scenic view when seen from the east, with the red marble complex of Hanumangarhi rising in the background. According to a local priest, Buddhist pilgrims still come from as far away as Myanmar and Thailand, but apart from special occasions, Hindu pilgrims now bathe there infrequently (Kumar 2018: 141).

\section{(2) Vibhishan Kund}

The holy tank is the sacred place dedicated to Vibhishan, as guardian of the Ramadurga (the fortified town of the god Rama). He was the younger brother of demon king Ravana (of Sri Lanka) and supported Rama in the Great War with Ravana. The tank is in good condition, well-maintained steps on all sides, and is frequently visited by devout Hindus. Since 1958, when the Religious Trust Act reformation of the Uttar Pradesh government was passed, the local priest stewards the kund with the support of neighbors.

\section{(3) Vashishth Kund}

This kund, situated on the western side of the main road near Tedi Bazaar, is dedicated to the Guru Vashishth, who was the Royal Priest of Dasharatha (father of Lord Rama). Having navigable steps on all sides, this kund is kept in good repair by the Vashishth temple.

\section{(4) Brahma Kund}

Brahma Kund, situated between the Chakratirtha Ghat and Raj Ghat, is associated with the mythology of the attainment of Brahminhood by Vishvamitra (a nearly divine rishi or sage). Bathing in this kund is held to provide more merit during eclipses. The Brahma Kund Ghat (the steps leading to the water) attached to Brahma Kund was visited by Guru Nanak Dev (CE 1469-1539), the progenitor of Sikhism, on his journey from Haridvar to Puri (Johar 1976: 46, 132). The site is now in the hands of the Sikh community who have built a Gurudvara (sacred gathering place) there.

\section{(5) Dhanayaksha Kund}

Dhanayaksha Kund lies 500m north of the Chakratirtha Ghat and 300m south of Vashishth Kund. This kund is connected with Yakshas (vegetal divinities) and Kubera (a god of wealth), and thus this place is associated with the acquisition of wealth (Bakker 1986: II p. 249) and is believed to bestow beauty and fragrance. A mosque stands beside the road on the site of an old kund, and on the north-east side of the kund there 
is a small shrine of Yakshịnī (nature spirits) containing the usual stones and fragments as well as a new idol of Durga (the principal Hindu goddess of war) riding on a lion.

\section{(6) Brihaspati Kund}

Those suffering from an inauspicious horoscope seek this kund, which is situated on the Tedi Bazaar crossing road on the left side of Faizabad-Ayodhya main road. To prevent suffering from an unlucky alignment of the stars, bathers immerse themselves in this pond or perform a more elaborate shänti (peace rite) on the day of Brihaspativār (Thursday), when the planet Jupiter is in the most auspicious astrological position (Bakker 1986: 235-236). According to the mythology, Brihaspati (a Vedic-era sage who is also associated with Jupiter) once dwelt and performed a sacrifice at this place. The pacification rite performed at this place involves, firstly, a vow (saikalpa); secondly, a bath in the kund; thirdly, worship along with the donation of a golden image of Brihaspati (while standing in the water) and the offering of yellow cloths; and finally, a homa (sacrifice) accompanied by the recitation of formulas suited to appease the planetary deity.

\section{(7) Svarnakhani Kund}

Situated behind Badi Chhavani, this kund is associated with the legend of Raghu, an ancestor of Rama (an avatar of Vishnu), who had commemorated his conquest of the world (vishvajit) celebration and the donation of his property to the Brahmins at this site. According to mythology, to please king Raghu, Kubera (a deity of wealth) created a gold mine (svarnakhāni) at this site, which later became a holy water pool (Bakker 1986: 182; also, Bhagiratharam 2013: 76). The present structure at the kund was largely built by Saint Raghunath Das (CE 1817-1883) and his followers. It is a well-maintained quadrangular tank with steps on each side and a small folk Devi temple in the northeast corner containing remarkable idols (Kumar 2018: 143).

\section{(8) Sita Kund}

The sanctity of Sita Kund, lying two kilometers southeast of the Ayodhya railway station (see Fig. 6), derives from the bestowing of mukti (liberation from the transmigration). According to mythology, Sita Kund was built by Sita (wife of Lord Rama) and became famous for its holiness due to favor granted to her by Rama. Every year, a great fair takes place at this kund celebrating the birthday of Sita, which falls on the 8th day of dark-fortnight (waning moon) in the Hindu month of Phalguna, February-March (Sitaram 1933: 71). The present structure, developed during the 1970s, is covered with trees and flowering shrubs.

\section{(9) Vidya Kund}

Lying 200m east of the Mani Parvata, in the inner courtyard of the Mahavidya temple complex, is the well-maintained, square-shaped Vidya Kund, which has steps on 
each side. A shrine or temple of Vidya Devi (the goddess of knowledge Sarasvati) is located on the south side of the holy tank whereas the west side was said to contain a Vidyapitha (a seat of learning), which might have been a religious institution of learning. This kund was said to be the place where Lord Rama was taught by Vashishtha in the fourteen basic sciences (Bakker 1986: 206).

\section{( 10$)$ Kharju Kund}

Kharju Kund lies $650 \mathrm{~m}$ south of Vidya Kund. According to mythology, bathing in this holy tank cures the bather of itching and skin diseases. Most efficacious are bathing on Sundays, the day associated with the curative powers of the sun god (Sürya) concerning to skin diseases.

\section{( I I) Durbhara Sar and Mahabhara Sar}

Durbhara Sar is a small natural pond that lies $1300 \mathrm{~m}$ southwest of Vidya Kund, and Mahabhara Sar lies a further $150 \mathrm{~m}$ south. These sacred sites are associated with the worship of Shiva and Vishnu, respectively. According to mythology, these ponds are linked to two florist brothers, Durbhara and Mahabhara, who attended to Shiva and Vishnu whenever they were deliberating on the earth and offered them lotus flowers (Bakker 1986: 224). Pleased by the special offering, the two gods granted favor to the brothers, providing two holy water pools full of lotus flowers that were to be used to please the gods (Bhagiratharam 2013: 76-77). Today Mahabhara Sar is partially filled in and Durbhara Sar remains only as a ditch, and there are no temples and shrines connected with either of these two places (Kumar 2018: 144). Nevertheless, every year a religious gathering (mela) of devotees is held as a commemoration of the 12th light-fortnight (waxing) of the Hindu month of Vaishakha (April-May).

\section{(I2) Surya (Suraj) Kund: a model for water pool development}

On the Chaudahkroshi route at its south bend lies Surya Kund, a spectacular water tank possessing stone steps on all sides in a serene natural environment (Fig. 7). This site was renovated and rebuilt in its present form by King Darshan Singh in the seventeenth century (Irwin 1880: 107). This pool lies to the southeast of the neighborhood of Darshan Nagar, approximately 300 meters west of Vaitarini, another water spot that grants relief from the curse of Yama, the "god of death" (Bakker 1986: 297). On its western side, on a raised platform, stands the square temple of Surya (Suraj) in which a modern idol of Surya (the sun god) resides (Bakker 1986: 99). Steps on the eastern, northern, and southern sides lead up to the temple platform. Beside the temple is a small shrine enclosing a Shiva lingam. The side-by-side locations of Surya (a cosmic God) and Shiva (a God of wild nature) remind pilgrims of the ancient link between the two groups of deities and form the most popular tradition in Hinduism. 
Figure 7. Ayodhya: the Surya (Suraj) Kund (bird's eye view from Google).

Figure 8. Surya (Suraj) Kund, Ayodhya: Comprehensive Development Plan (with courtesy, after Nishant Upadhyay of 'Dharātal', Lucknow).
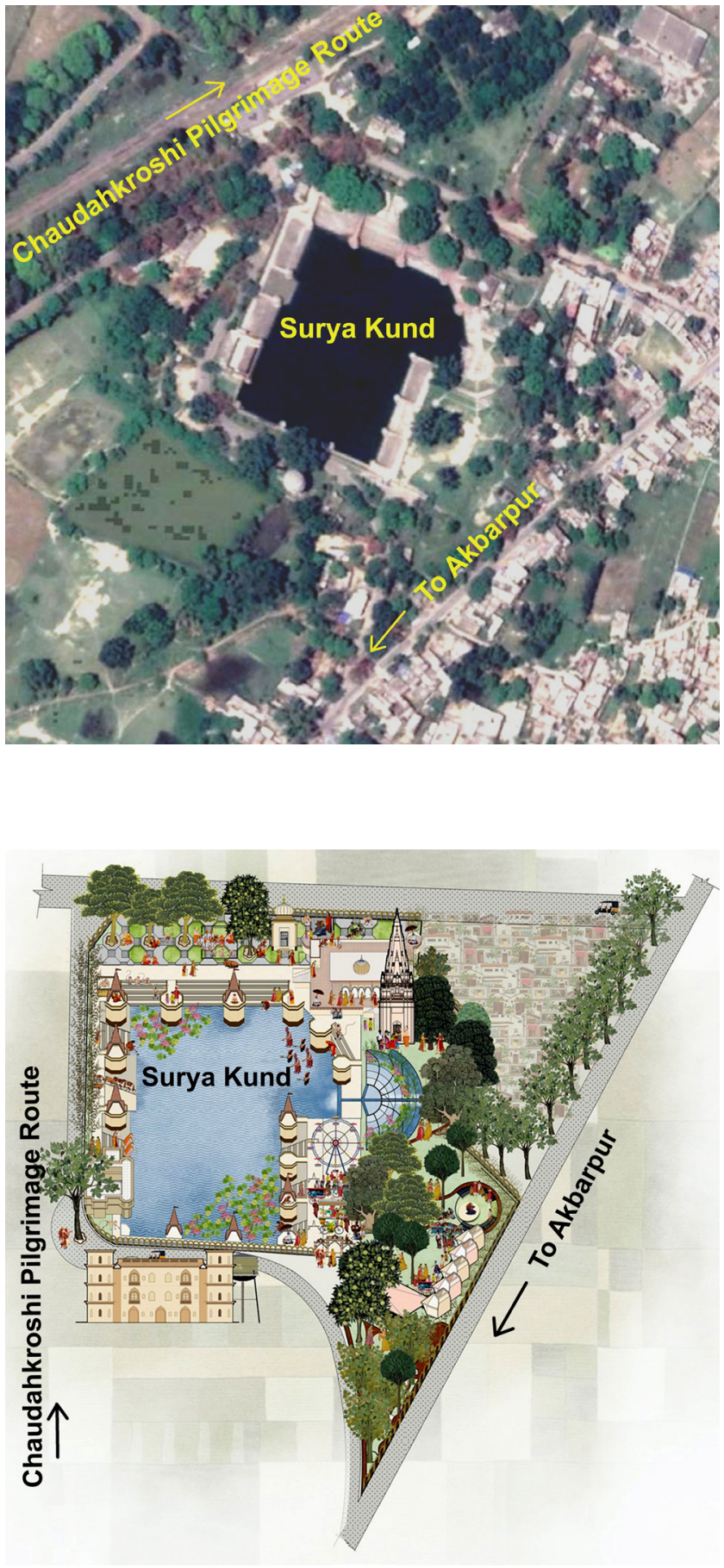
The history of this grand water pool goes back to the CE eleventh century, where it stood as an old sanctuary of the sun god, possibly linked to a historical king or chieftain named Ghosha, in whose memory this tank is also known as Ghosharka Kund. The sun cult in India was prevalent during the Shaka dominance in western India (i.e., 1st century BCE, see Gail 1978: $346 \mathrm{fn}$ ). Worship here is associated with the power of the Sun to cure skin diseases (see the Samba Purāna, 3.1-26). The curative properties of the water are thought to be strongest when exposed to the sun's rays.

Every Sunday devout Hindus pay a visit to Surya Kund and perform oblations and common rituals in the name of the sun goddess, following the ancient tradition of "Gayatri," the primordial feminine source of life on the Earth (see Rig Veda 3.62.10). Therefore, in this form, the sun is eulogized as the mother of fertility (see Singh 2010). Additionally, there are four special occasions to visit this kund as described in the ancient tales: (1) every Sunday, coinciding with the 7th day of the lunar (Hindu) month (waxing and waning fortnights), (2) Bhadrapada Shukla (August-September), on the 6th day of the light-fortnight (waxing moon), (3) Magha Shukla (January-February, light fortnight) on the 6th, and (4) Pausha (DecemberJanuary), again, particularly on Sundays. As in the case of Lolark Kund in Varanasi, these festivities are performed mostly by married Hindu women, of course with the support of elder male members of the family.

Under the heritage-inclusive development plan of Ayodhya within the Master Plan (2021-2041), state government initiatives aim to revive the ancient tradition of worshipping under the purview of Vedic traditions to protect and preserve sacred water and related intangible heritage traditions (e.g., the associated pilgrimages and festivities). This initiative also relates to promoting pilgrimage tourism and Hindu identity, together with re-establishing the glory of sacred landscapes in holy heritage cities like Ayodhya. The sacred territorial limit of the main city of Ayodhya is defined by the circumambulatory route of Chaudahkroshi Yatra (the pilgrimage route) covering forty-nine kilometers and interlinking thirty-four popular sacred places related to Lord Rama, archetypally representing the spots mythologizing his birthplace to the place of his death. These thirty-four sacred spots are classified into five categories, viz. river and waterfront sites (16), sacred water pools (10), temples (3), sanctuary and sacred groves (3), and monasteries (2). Among these the southeast edge is marked by Surya Kund, which stands as the most popular and spectacular spot (Kumar 2018: 176-177). In this way, Surya Kund has served as a model, and a comprehensive plan is being prepared (see Fig. 8) that emphasizes spaces for spiritual engagement, yoga practice, a circumambulation path, areas for priests, platforms for religious discourses, and lectures. The plan also aims to restore the lush vegetation of the area with sacred and healing plants and trees. This spot also serves as an important night halt for pilgrims; those making a three-day ambulatory pilgrimage will be facilitated by pilgrim guesthouses there. Recent government policy for the promotion of Hindu identity and the ancient glory of the city has developed in conjunction with the ASI (Archaeological Survey of India) and jurisdictive regulations. A large temple complex is also under construction (expected to be completed by March 
2023) at the Ramajanmabhumi (birthplace of Lord Rama). Rama belonged to the solar dynasty, whose patron deity and royal symbol was the Sun (Sūrya). His ancient story has further supported the planning strategy to develop Surya Kund as a model for waterfront development, which befits the belief systems of the Hindu masses.

\section{Concluding remarks: towards sacred ecology}

In comparison to other sacred sites, sacred water spaces are charged with more liminality. They are places that, in the past and still today, exist on the margins of a structured world. Over time these places began to assume an ambiguity, with the exact meaning and practices of each being regularly renegotiated through the generations; however, they still retain their basic essence in the religious performances and festivities. Of course, those tanks or natural ponds with minor roles in mythology have lost their identity in the physical milieu, perhaps being replaced by a replicated version such as a constructed well. Many others have lost their spiritual affinity through their illegal seizure and are presently used simply as water sources. However, many of these remain memorable spots, serving only for occasional and abbreviated forms of rituals. Nevertheless, the majority of devout Hindus still pay their reverence to them. These water spots are liminal places, "thresholds" interconnecting the physical realm of the Earth and the divine realm of the heavens. In fact, "Liminal places crossculturally, sacred springs and holy wells also have a numinous quality - many were perhaps selected as special because their physical distinctiveness suggested a supernatural character or presence. Supernatural guardians monitor these watery portals between realms and assist petitioners in accessing grace and thaumaturgical power across perceived divides between the natural and the supernatural" (Ray 2020: 12). The renovation and revival of Surya Kund in Ayodhya will foster new hope and a strategy for the restoration of salvific places. Of course, "the idea of salvific space has not only been challenged by environmental degradation but also by politicization and conflicts" (Jacobsen 2013: 165). Hearing and narrating sacred and old eulogies are good only for history, but not for the present history of ecological crises; let us realize it through self-retrospection while following the path of "realization" (anubhava) and march towards "revelation" (anubhüti). These issues are now considered in the envelope of resource management under the national mission of PRASAD (Pilgrimage Rejuvenation And Spiritual Augmentation Drive) initiated by the Government of India. Special attention is devoted to renovating and conserving the selected ancient sacred water pools with a view to reviving their role in ritual landscapes. This strategy promotes landscape ecology, will open new avenues for religious and spiritual tourism, and will enhance the local economy.

We need to revitalize the spiritual sense of ecology, a worldview of harmonic relationships between humanity and nature, and appreciate how surviving, age-old cultural traditions can teach us about heritage ecology. We have been on the verge of 
losing that relationship, as evident in dumping and the infilling of many such water pools in both Varanasi and Ayodhya, but thanks to the new mission of PRASAD, several positive measures are restoring sacred water places within the cities' Hindu sacredscapes.

\section{REFERENCES}

Agoramoorthy, Govindasamy. 2015. “Sacred Rivers. Their Spiritual Significance in Hindu Religion”. Journal of Religion and Health 54/3: 1080-1090. https://doi.org/10.1007/s10943-014-9934-z

Alter, Stephen. 2001. Sacred Waters. A Pilgrimage to the Many Sources of the Ganga. New Delhi: Penguin.

Baartmans, Frans. 2000. The Holy Waters. A Primordial Symbol in Indian Myths. Delhi: B.R. Publishing.

Bhagiratharam, Brahmachari. 2013. Ayodhyā Darpana ('Mirror of Ayodhya'), edited by Ganeshadas 'Bhaktamali.' Ayodhya: published by the author. 4th edition (first published in 1992). [in Hindi].

Bakker, Hans T. 1986. Ayodhya. The History of Ayodhya from the $17^{\text {th }}$ Century BC to the Middle of the $18^{\text {th }}$ Century. Groningen: Egbert Forsten.

Derné, Steve. 1998. "Feeling Water. Notes on the Sensory Construction of Time and Space in Banaras". Man in India 78/1-2: 1-7.

Eck, Diana L. 1982. Banaras, City of Light. New York: Alfred A. Knopf Inc.

Eliade, Mircea. 1958. Patterns in Comparative Religion. Trans. Rosemary Sheed. London: Sheed and Ward.

Gail, Adalbert J. 1978. "Der Sonnenkult im alten Indien. Eigengewächs oder Import”. ZDMG, Zeitschrift der Deutschen Morgenländischen Geselllschaft 128: 333-348.

Gita Press. 1957. Tìrthāinka-Kalyāna. Annual No. 31. Gorakhpur: Gita Press. [Popular essays on 1820 pilgrimage places of India; in Hindi].

Gutschow, Niels. 2006. Benares. The Sacred Landscape of Värānasī. Stuttgart, London: Edition Axel Menges.

Irwin, Henry Crossley. 1880. The Garden of India or Chapters on Oudh History and Affairs. London: W.H. Allen.

Jacobsen, Knut A. 2013. Pilgrimage in the Hindu Tradition. Salvific Space. London, New York: Routledge. https:// doi.org/10.4324/9780203102510

Johar, Surinder S. 1976. The Sikh Gurus and their Shrines. Delhi: Oxford University Press.

Kane, Pandurang Vaman. 1975. History of Dharmashashtra. Ancient and Mediaeval Religions and Civil Law in India III. Pune: Bhandarkar Oriental Research Institute.

Kumar, Sarvesh. 2018. Cultural Landscape and Heritage of Ayodhya-Faizabad. A Geographical Analysis. Unpublished doctoral dissertation in Geography, Faculty of Arts, B.H.U. Varanasi: Banaras Hindu University.

Kumar, Sarvesh and Rana P.B. Singh. 2013. "Waterfront Cultural Landscape of Ayodhya (India), an Ancient Sacred Abode of Gods”. South Asian Affairs 9: 6-17.

Lazzaretti, Vera. 2020. "Sacred Wellwells of Banaras. Glorificationns, Ritual Practicees and Healing”. In Sacred Waters. A Cross-Cultural Compendium of Hallowed Springs and Holy Wells. Celeste Ray, ed. London, New York: Routledge, 159-167. https://doi.org/10.4324/9781003010142-18

Panikkar, Raimundo. 1985. Vedic Experience. An Anthology of Hinduism's Sacred and Revealed Scriptures. New Delhi: Motilal Banarsidass on behalf of Himalayan Academy.

Pathak, Ratnesh K. and Cynthia A. Humes. 1993. "Lolark Kund. Sun and Shiva Worship in the City of Light". In, Living Banaras. Hindu Religion in Cultural Context. Bradley R. Hertel and Cynthia A. Humes, eds. Albany, New York: Suny Press, 205-244.

Prinsep, James. 1831, 1833. Benares Illustrated in a Series of Drawings. Lithographed in England by Eminent Artists. I to III Series. Calcutta, London: Baptist Mission Press, Smith, Elder and Co. [Note: The map was first published in 1822 , and included in this work].

Ray, Celeste. 2012. "Beholding the Speckled Salmon. Folk Liturgies and Narratives of Ireland's Holy Wells". In Landscapes Beyond Land. Routes, Aesthetics, Narratives. Arner Arnason, Nicolas Ellison, Jo Vergunst and Ándrew Whitehouse, eds. New York, Oxford: Berghahn Books, 139-159.

Ray, Celeste. 2019. "Sacred Wells across the Longue Durée”. In Historical Ecologies, Heterarchies and Transtemporal Landscapes. Celeste Ray and Manuel Fernández-Götz, eds. London, New York: Routledge, 265-286. https:// doi.org/10.4324/9781351167727-16

Ray, Celeste. 2020. "Holy Wells and Sacred Springs". In Sacred Waters. A Cross-Cultural Compendium of Hallowed Springs and Holy Wells. Celeste Ray, ed. London, New York: Routledge, 1-31. https://doi. org/10.4324/9781003010142-1

Sherring, Matthew Atmore. 1868. Benares, the Sacred City of Hindus. London: Trübner and Co.; reprinted in 1975, Delhi: B.R. Publishing Co. 
Singh, Rana P.B. 1994. "Water Symbolism and Sacred Landscape in Hindūism. A Study of Benares (Varanasi)". Erdkunde, Archiv für Wissenschaftliche Geographie 48/3: 210-227. https://doi.org/10.3112/erdkunde.1994.03.05

Singh, Rana P.B. 2010. “The Sun Goddess Festival, 'Chhatha', in Bhojpur Region, India. An Ethnogeography of Intangible Cultural Heritage”. Asiatica Ambrosiana 2: 59-80.

Singh, Rana P.B. 2013. Hindu Tradition of Pilgrimage. New Delhi: Dev Publishers and Distributors.

Singh, Rana P.B. 2020. "Sacrality and Waterfront Sacred Places in India. Myths and the Making of Place". In Sacred Waters. A Cross-Cultural Compendium of Hallowed Springs and Holy Wells. Celeste Ray, ed. London, New York: Routledge, 80-94. https://doi.org/10.4324/9781003010142-9

Singh, Rana P.B. and Pravin S. Rana. 2016. "Indian Sacred Natural Sites. Ancient Traditions of Reverence and Conservation Explained from a Hindu Perspective”. In Asian Sacred Natural Sites. Ancient Philosophy and Practice in Conservation and Protected Areas. Bas Verschuuren and Naoya Furuta, eds. London, New York: Routledge, 69-80.

Singh, Rana P.B., Pravin S. Rana, and Daniel H. Olsen. 2022. “The Environment as Sacred Space. Religious and Spiritual Tourism in Hinduism”. In Routledge Handbook of Religious and Spiritual Tourism. Daniel H. Olsen and Dallen J. Timothy, eds. London, New York: Routledge, 135-151. https://doi.org/10.4324/9780429201011-12

Sitaram, Lala. 1933. Avadh Ki Jhanki. Prayaga: Orient Books.

\section{Sveti vodeni bazeni hinduističkih svetih krajolika u sjevernoj Indiji}

Osnovni metafizički okvir života u drevnoj Indiji, onaj svete vode (pavițra jala), te predodžba da je "voda sam život” (jala hī jivan hai) mogu se ilustrirati studijama slučaja dvaju gradova. Nastanjeni kontinuirano od 1000. godine prije Krista, gradovi Varanasi i Ayodhya u Indiji slave se kao spasiteljski sveti i baštinski gradovi, poznati po svojim obrednim krajolicima povezanima sa svetim vodama i bazenima. Prema drevnim raspravama i pričama, u svakom od tih gradova postojale su pedeset i četiri svete cisterne (kunds) i bunara (küpas), koji su postali važna mjesta za rituale pročišćavanja, hodočašće, ozdravljenja i svečana slavlja pobožnih hinduista. Nakon opisa svetih vodenih bazena, u radu se djelomično istražuju tradicije vezane uz vodene bazene posvećene bogu sunca u oba grada. $U$ širem smislu, koristeći se drevnim tekstovima, današnjim participativnim anketama $i$ etnološkim pripovijedanjem, $u$ radu se razmatra dugovječna sakralnost vodenih bazena u spomenutim gradovima te s njima povezane aktualne razvojne strategije.

Ključne riječi: Ayodhya, sveti i baštinski gradovi, Lolark Kund, hodočasnički turizam, sveta voda, Suraj Kund, Varanasi 